\title{
Silencing of endogenous IGFBP-5 by micro RNA interference affects proliferation, apoptosis and differentiation of neuroblastoma cells
}

\author{
B Tanno ${ }^{1}$, V Cesi ${ }^{1}$, R Vitali ${ }^{1}$, F Sesti ${ }^{1}$, ML Giuffrida ${ }^{1}$, C Mancini ${ }^{1}$, \\ B Calabretta ${ }^{2}$ and G Raschellä ${ }^{\star 1}$ \\ 1 ENEA Research Center Casaccia, Biotechnology Unit, Section of Toxicology \\ and Biomedical Sciences, Via Angullarese, 301, 00060 S. Maria di Galeria, \\ Rome, Italy \\ ${ }^{2}$ Kimmel Cancer Center, Thomas Jefferson University, 19107 Philadelphia, PA, \\ USA \\ * Corresponding author: G Raschellà, ENEA Research Center Casaccia, \\ Biotechnology Unit, Section of Toxicology and Biomedical Sciences, Via \\ Anguillarese, 301, $00060 \mathrm{~S}$. Maria di Galeria, Rome, Italy. \\ Tel: + 39-063048-3172; Fax: + 39-063048-6559; \\ E-mail: raschella@ casaccia.enea.it
}

Received 27.5.04; revised 28.10.04; accepted 02.11.04; published online 24.12.04 Edited by CJ Thiele

\begin{abstract}
Signal transduction through the IGF axis is implicated in proliferation, differentiation and survival during development and adult life. The IGF axis includes the IGF binding proteins (IGFBPs) that bind IGFs with high affinity and modulate their activity. In neuroblastoma (NB), a malignant childhood tumor, we found that IGFBP-5 is frequently expressed. Since NB is an IGF2-sensitive tumor, we investigated the relevance and the function of endogenous IGFBP-5 in LAN-5 and in SY5Y(N) cell lines transfected with micro and small interfering RNAs directed to IGFBP-5 mRNA. Cells in which IGFBP-5 expression was suppressed were growth-inhibited and more prone to apoptosis than the parental cell line and controls. Apoptosis was further enhanced by X-ray irradiation. The ability of these cells to undergo neuronal differentiation was impaired after IGFBP-5 inhibition but the effect was reversed by exposure to recombinant IGFBP-5. Together, these data demonstrate the importance of IGFBP-5 for NB cell functions and suggest that IGFBP-5 might serve as a novel therapeutic target in NB.

Cell Death and Differentiation (2005) 12, 213-223.

doi:10.1038/sj.cdd. 4401546

Published online 24 December 2004
\end{abstract}

Keywords: IGFBP-5; neuroblastoma; proliferation; apoptosis

Abbreviations: DTT, dithiothreitol; EDTA, ethylene diamine tetra-acetic acid; ELISA, enzyme-linked immuno-sorbent assay; RT-PCR, reverse transcriptase-polymerase chain reaction; SDS, sodium dodecyl sulfate

\section{Introduction}

In mammals, the IGF axis is one of the most important signal transduction pathways whose activity is necessary from embryonic development throughout adult life. ${ }^{1}$ Two low molecular weight cytokines, IGF1 and IGF2, are ligands of the main receptor IGF1R. ${ }^{2}$ Both IGFs play important roles in cell proliferation and differentiation during development. ${ }^{3}$ In adults, these factors are involved in the normal function of reproductive, immune and cardiovascular systems. ${ }^{4}$ In the nervous system, IGFs are able to inhibit apoptosis during aging and neuronal degeneration. ${ }^{5}$ The central role of IGF1R in cell growth during development is exemplified by the phenotype of IGF1R knockout mice. These animals, although viable, are approximately half the size of their wild-type counterparts. ${ }^{6}$ Many intracellular proteins are involved in transduction of IGF signals from the membrane to the nucleus. ${ }^{7}$ Some proteins are specific to this pathway, while others represent ubiquitous components of several transduction cascades. The activity of IGF axis is finely regulated not only by the availability of IGF factors and density of the IGF1R on the cell surface but also by a family of six proteins, the IGF binding proteins (IGFBPs), which bind IGF with high affinity. ${ }^{8}$ IGFBPs are not only carriers of IGF factors but, at least IGFBP-3 and -5 , can also bind the extracellular matrix (ECM), thus reducing their affinity for IGFs and allowing an optimal exchange of the factors with IGF1R, ${ }^{9,10}$ potentiating the IGF signaling. In addition, IGFBP-5 has been demonstrated to function as IGF-independent cytokine in bone cells. ${ }^{11}$ Intriguingly, the function of IGFBP-5 seems tissue-specific and dosage-dependent. In bone ${ }^{11}$ and smooth muscle cells, ${ }^{12}$ this protein promotes proliferation. In human intestinal smooth muscle cells, the proliferative effect of IGFBP-5 depends on the Ras-dependent activation of p38 MAP-Kinase and the ERK1/2 pathways. ${ }^{13} \mathrm{~A}$ decrease in IGFBP-5 gene expression following growth inhibition of the rat mammary gland has been reported. ${ }^{14}$ On the contrary, during the involution of the mammary gland IGFBP-5 acts as inhibitory factor. ${ }^{15}$ Recent work also reports growth inhibition by IGFBP-5 in human breast cancer cells in vitro and in vivo. ${ }^{16}$ In contrast with these data, IGFBP-5 has been involved also in apoptotic processes in various cell types with different findings dependent on the cell type analyzed. In prostate ${ }^{17}$ and mammary ${ }^{18}$ glands and in the rat brain following hypoxic-ischemic injury, ${ }^{19}$ increased expression of IGFBP-5 has been associated with apoptotic processes. In contrast, Perks et al..$^{20}$ have demonstrated a protective effect of IGFBP-5 in human breast cancer cells following a proapoptotic stimulus with ceramide. Also in cerebellar granule cells, the induction of apoptosis has been associated with downregulation of IGFBP-5. ${ }^{21}$ Interestingly, this effect can be reversed by IGF1 administration. ${ }^{21}$

The activity of the IGF axis is important not only in normal tissues but also in many types of tumors that are sensitive or dependent on the availability of IGF factors. ${ }^{22,23}$ Neuroblastoma (NB), a childhood tumor originating from the embryonic neural crest, is IGF2-sensitive. ${ }^{24}$ Although many clinical and genetic markers of NB are commonly used to help the 
clinicians in defining diagnosis and prognosis of this neoplasia (see for an extensive review Brodeur ${ }^{25}$ ), the outcome of stage 3 and 4 patients remains poor. NB preferentially metastasizes at distant sites where a paracrine support of IGF2 is available. ${ }^{24}$ In some aggressive NB tumors as well as in many NB cell lines, autocrine production of IGF2 is detectable. $^{26}$ Recently, we demonstrated that IGFBP-5 transcription is stimulated by $\mathrm{c}-\mathrm{Myb}$ and $\mathrm{B}-\mathrm{Myb}$ oncoproteins in NB cells through direct and indirect mechanisms. ${ }^{27}$ In the same cells, IGFBP-5 administration causes dose-dependent opposite effects: low amounts of recombinant protein added to the medium stimulated proliferation while a high concentration reduced cell growth. ${ }^{27}$ Since expression of IGFBP-5 is commonly detected in NB cells, ${ }^{28}$ an obvious question is whether the endogenous IGFBP-5 production in cells that are sensitive to IGF factors is functionally relevant.

Silencing through siRNA or micro RNA is a natural mechanism for suppression of specific gene activity that is highly conserved in evolution. ${ }^{29,30}$ The use of siRNA and micro RNA in mammals has been very useful understanding the biological role of several genes using a relatively simple and efficient technique. ${ }^{29}$ The recent availability of plasmid and retroviral vectors, which are able to induce the synthesis of micro RNA targeted to a particular mRNA in mammalian cells, has allowed the production of stable cell lines in which the expression of a specific gene has been suppressed. ${ }^{31}$

In this paper, we carried out micro and small interfering RNA-mediated gene silencing to investigate the function of endogenous IGFBP-5 expression in NB cells. Using this approach, we were able to demonstrate relevant effects of IGFBP-5 on cell proliferation, apoptosis and differentiation in this tumor type.

\section{Results}

\section{Generation of IGFBP-5-interfered NB cells by micro RNA}

The human NB LAN-5 cell line expresses detectable levels of IGF2, IGF1R and IGFBP-5. ${ }^{27}$ We used a micro RNA-based strategy to inhibit the expression and assess the functional role of the endogenous IGFBP-5 in these cells. To this end, we engineered an expression vector (pMIREV), which transcribes hairpin RNAs from the human U6 promoter $^{32}$ and contains the puromycin resistance gene for selection in eukaryotic cells (details of the procedure to obtain pMIREV are given in the Materials and Methods). Hairpin RNAs are processed in the cells by the ubiquitous type III endonuclease Dicer to become micro RNAs which are shuttled to the target messenger RNAs in a multiprotein complex ${ }^{30}$ and generate heteroduplex micro RNA/target mRNA that cannot be translated into a protein. To assess the effectiveness of pMIREV in inhibiting the expression of specific genes, we cloned into this vector a sequence known to generate a micro RNA that inhibits the expression of the firefly luciferase protein. ${ }^{33}$ NB cells were transfected with this vector together with a reporter vector that transcribes firefly luciferase. At $36 \mathrm{~h}$ after transfection, luciferase activity was measured and compared with that of a control test in which the reporter vector was cotransfected with the empty pMIREV. Compared with the controls, the anti-firefly luciferase micro RNA generated by pMIREV ILuc was able to specifically inhibit luciferase activity by approximately $60 \%$.

Three different target sequences named 1, 2 and 3 located at the $3^{\prime}$ UTR of the human IGFBP-5 mRNA (see Figure 1a) were selected using a program designed to identify the best fit regions for interference by micro RNAs (see Materials and Methods). The corresponding DNA sequences that can be transcribed in hairpin RNAs were cloned into pMIREV. The resulting constructs were transfected into LAN-5 cells and puromycin-resistant cells were selected and expanded for 28 days in the presence of $1 \mu \mathrm{g} / \mathrm{ml}$ puromycin. To designate the single clones obtained after selection, we used the following nomenclature: each clone was named I (for Interfered) followed by a number indicating the target region (1,2 or 3) at which the micro RNA was targeted, followed by a letter indicating that particular clone (A, B, C, etc.). A parallel experiment was carried out by transfecting the pMIREV Iluc vector containing the sequence that was able to inhibit luciferase (see above). The clones obtained from this transfection were named ILuc and used as controls. We

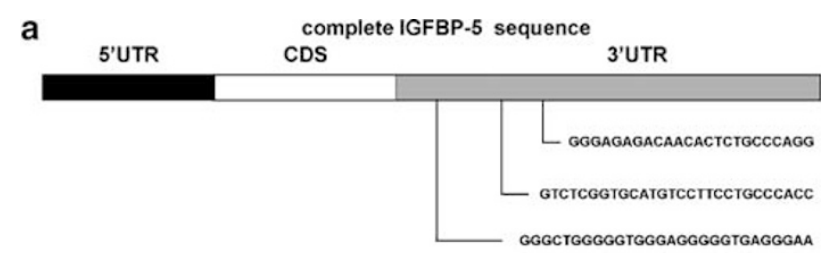

b

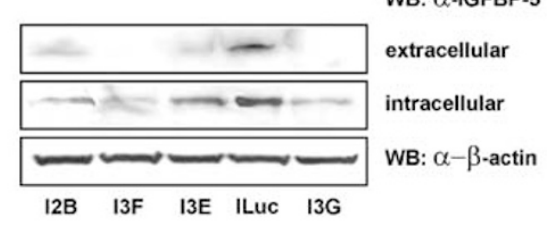

C
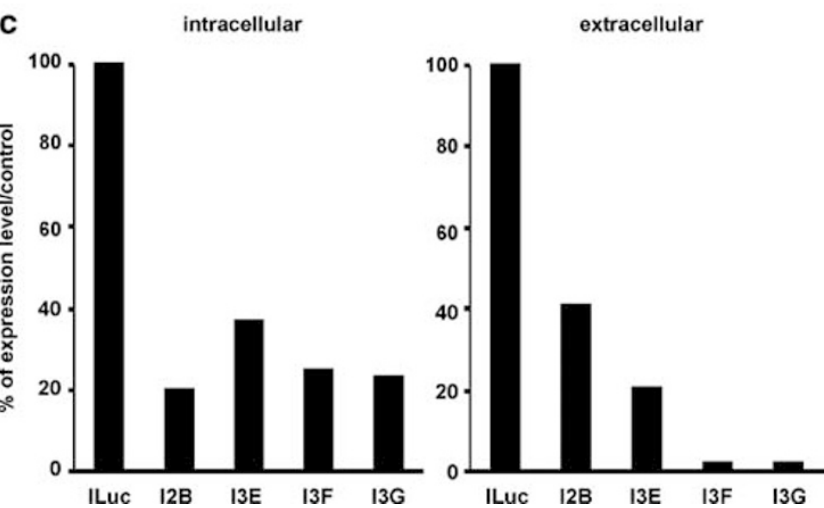

Figure 1 Characterization of IGFBP-5-interfered clones. (a) Location of three sequences selected for micro RNA-mediated interference in the 3'UTR of human IGFBP-5 gene. (b) Western blot analysis of IGFBP-5-interfered clones and controls. The upper blot was carried out with equal amount of culture supernatants after protein concentration and the lower blot was carried out with cellular extracts. Blots were probed with specific anti-IGFBP-5 antibody and the intracellular proteins were normalized for $\beta$-actin content. Experiments were repeated twice with similar results. (c) Densitometric measurements of IGFBP-5 protein (detected in $\mathbf{b}$ ) in the intra- (left) and extracellular (right) compartments of selected interfered clones and controls. Measurements refer to one of two identical WB experiments 
carried out Western blot analysis to detect IGFBP-5 protein in the extra- and intracellular compartments of transfected cells. Levels of IGFBP-5 were reduced by different extents, most likely due to the variable number of transcriptional units of micro RNA inserted into the genome, in clones transfected with interfering sequences corresponding to regions 2 and 3 as compared with the ILuc control (Figure 1b). In contrast, cells transfected with interfering sequences corresponding to region 1 did not show any decrease in IGFBP-5 expression levels (not shown). A densitometric analysis of the IGFBP-5specific bands is shown in Figure 1c. In some instances, transfection of retroviral or plasmid vectors producing micro RNA could induce an interferon-like response with the activation of specific genes and nonspecific decrease in translation activity. ${ }^{34}$ To rule out this possibility, we monitored the levels of expression of the interferon-induced oligoadenylate synthase 1 (OAS1) gene ${ }^{35}$ by reverse transcriptase (RT)-PCR in transfected clones and in controls. Compared with controls, there was no variation in OAS1 RNA levels in the IGFBP-5-interfered clones (Figure 2a). On the other hand, quantitative real-time $\mathrm{PCR}$ analysis showed a detectable increase of IGF2 RNA transcripts in IGFBP-5-interfered clones at 4 days from plating (Figure $2 b$ ). To assess whether the increase in IGF2 mRNA correlated with enhanced protein levels, an ELISA test was carried out in interfered clones and controls 4 and 6 days from plating (Figure 2c). A timedependent IGF2 accumulation in the supernatants was detectable in interfered clones and in controls (compare white and black bars in Figure 2c). Of note, the levels of IGF2 protein in the interfered clones did not show the striking increase

a
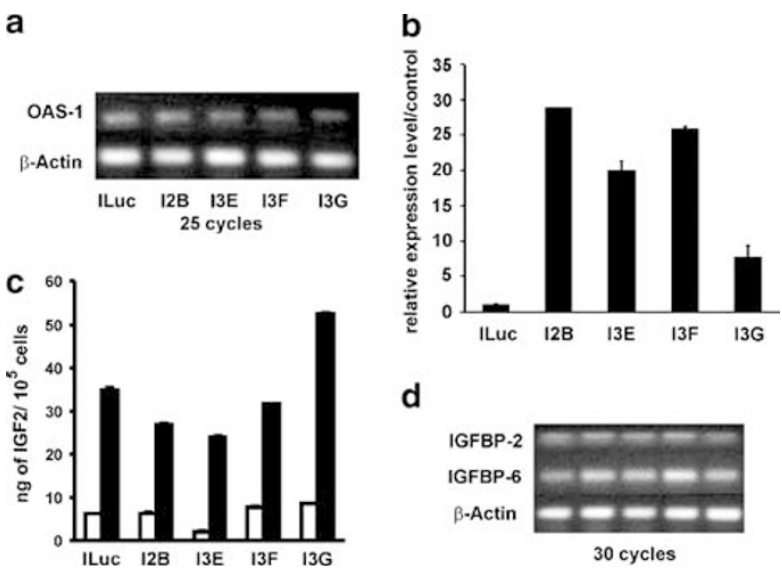

d

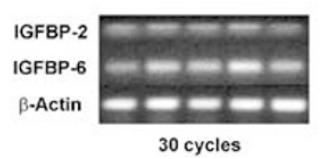

Figure 2 (a) Semiquantitative reverse transcription (RT)-PCR on RNA of clones and controls. PCR reactions were carried out using a pair of primers specific for the oligoadenylate synthase 1 (OAS-1) and $\beta$-actin genes for the indicated number of cycles. (b) Quantitative (real-time) PCR of IGF2 was carried out on CDNA reverse transcribed from RNA of IGFBP-5-interfered clones and controls maintained in standard growth conditions (RPMI $1640+10 \%$ FCS) after 4 days from plating. The expression level of the cytokine in control ILuc was taken as 1. Samples were normalized for the expression of $\beta$-actin (see Materials and Methods for details). The experiment was carried out in triplicate. (c) ELISA test to detect the expression of IGF2 protein. Cells were grown in $10 \%$ FCS and the analysis was carried out on culture supernatants after 4 (white bars) and 6 days (black bars). The amount of IGF2 detected in the medium $+10 \%$ FCS in the absence of cells was subtracted from each experimental point. The amount in nanograms of IGF2 was referred to $10^{5}$ cells. Each bar was represented \pm S.D. (d) Semiquantitative reverse transcription (RT)-PCR on RNA of clones and controls to determine the expression of other IGFBPs observed for the IGF2 mRNA transcripts. The amount of IGF2 protein fluctuated from a maximum of $52.63 \pm 0.31$ to a minimum of $23.91 \pm 0.36 \mathrm{ng} / 10^{5}$ cells in I3G and I3E, respectively, 6 days after plating (Figure 2c). In summary, there was not a significant compensatory increase of IGF2 proteins in IGFBP-5-interfered clones. Moreover, semiquantitative RT-PCR analysis to detect the expression of IGFBP-1, $-2,-3,4,-6$ in IGFBP-5-interfered clones did not reveal IGFBP-1, -3 and -4 mRNA transcripts in all samples tested (not shown), while IGFBP-2 and -6 levels were essentially identical in the interfered clones and in the control. (Figure $2 d$ ).

\section{IGFBP-5 interference causes growth inhibition of NB cells}

During the selection process, we noted that cells transfected with sequences aimed at interference of regions 2 and 3 grew very slowly. On the contrary, cells transfected with sequences aimed at interference of region 1 and ILuc controls grew like the parental cell line. Therefore, we set up experiments to determine the proliferation rate of some IGFBP-5-interfered clones. Cells were seeded in medium supplemented with $10 \%$ FCS and allowed to grow for $192 \mathrm{~h}$ (8 days). At the last time point, the number of IGFBP-5-interfered cells was consistently lower than in controls (Figure $3 a$ ) with a percent reduction ranging from $20.10 \%$ (I3G) to $68.59 \%$ (I3F). These differences in cell numbers were evident after 4 days but did
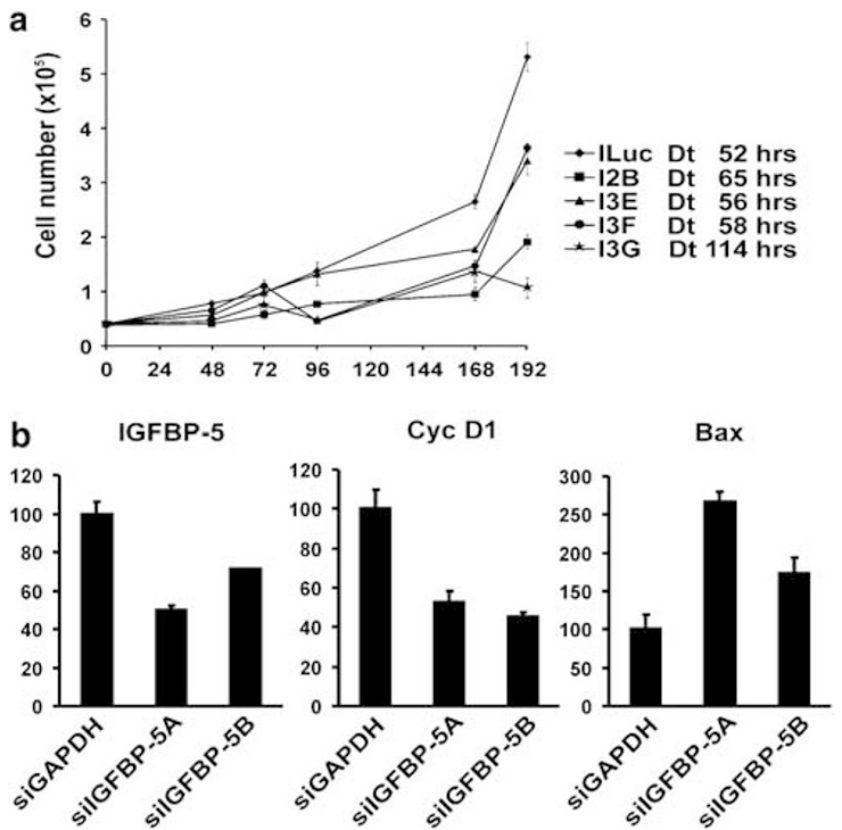

Figure 3 Effects of IGFBP-5 interference on cell proliferation. (a) Proliferation assays of IGFBP-5-interfered clones and controls were carried out in RPMI 1640 supplemented with $10 \%$ FCS. Cells were seeded and allowed to grow for $192 \mathrm{~h}$ (8 days) and counted at different time points. Doubling times (Dt) were calculated as described in Materials and Methods. Bars represent standard deviations. (b) Effects of IGFBP-5 interference in SY5Y(N) cells. Cells were transfected with siRNA directed against two regions ( $A$ and $B$ ) in the $3^{\prime}$ UTR of the IGFBP-5 gene. A control transfection was carried out using siRNA directed against GAPDH. Expression of IGFBP-5, cyclin D1 and Bax was determined by quantitative realtime PCR taking the expression of control (siGAPDH) as 100. Bars represent standard deviations 
not seem to be caused by different availability of growth factors in the cultures since the levels of IGF2 protein are comparable after 6 days (Figure 2c). The calculated doubling times were extended up to $114 \mathrm{~h}$ (I3G) compared with the $52 \mathrm{~h}$ of the control (ILUC) transfectant (Figure 3a), which behaved similarly to the parental cell line LAN-5. Cell viability of IGFBP5-interfered cells was monitored by a specific assay (WST-1), which analyzes the metabolic activity by measuring cell viability (details of this assay are given in the Materials and Methods). In these experiments, we used $7.5 \%$ heatinactivated fetal calf serum to minimize the exogenous supply of biological active growth factor contained in the serum. We found that viability of the IGFBP-5-interfered cells was reduced to $58.6 \%$ compared to the ILuc control taken as 100 after $72 \mathrm{~h}$ of culture (see Table 1). Since the effect of IGFBP-5 silencing in LAN-5 cells could be limited to this particular cell line, we carried out IGFBP-5 interference on SY5Y(N), another human NB cell line. ${ }^{36}$ We synthesized 3 siRNA, (A, B and $C$ ) directed against three different sequences in the $3^{\prime}$ untranslated region of the human IGFBP-5 gene and transfected the SY5Y(N) cells by lipofection. At $48 \mathrm{~h}$ after transfection, RNA was extracted and quantitative real-time PCR was carried out to detect IGFBP5. siRNA $A$ and $B$ were able to induce a $50 \%$ inhibition of IGFBP-5 expression (Figure 3b, left panel). Of interest, also the expression of the cell cycle-related cyclin D1 was inhibited up to $45 \%$ in the IGFBP-5-interfered cells in correlation with the inhibition of cell proliferation (Figure $3 b$, center panel). This experiment suggested that the effect of IGFBP-5 inhibition on cell proliferation was not limited to one NB cell line.

Tumor cells often acquire the ability to grow in an anchorage-independent manner in vitro. ${ }^{37}$ Thus, we tested whether inhibition of IGFBP-5 expression could affect this capacity by culturing IGFBP-5-interfered and control cells in semisolid agar for 11 days. On counting the number of clones (i.e. groups of more than 20 cells), the clonogenic activity of

Table 1 Proliferation/cell viability of IGFBP-5-interfered cells

\begin{tabular}{lc}
\hline Clone & \% of proliferation \\
\hline Iluc & $100 \pm 7$ \\
I2B & $58.6 \pm 1.9$ \\
I3E & $61.7 \pm 1.0$ \\
I3F & $75.2 \pm 2.0$ \\
I3G & $59.4 \pm 1.2$
\end{tabular}

Cell proliferation of IGFBP-5-interfered cells compared with control cells (taken as 100) was measured with a specific assay (WST-1). In all, $4 \times 10^{4}$ cells/well were seeded in RPMI $1640+7.5 \%$ heat-inactivated FCS for $72 \mathrm{~h}$. The experiment was carried out in triplicate cultures
IGFBP-5-interfered cells was markedly reduced compared with controls (Table 2). In addition, clones developing from IGFBP-5-interfered cell cultures were markedly smaller than those in controls (Figure 4).

\section{IGF-dependent and IGF-independent effects of IGFBP-5 on cell proliferation of NB cells}

IGFBP-5 alongside its IGF-dependent activity may function as a cytokine per se. ${ }^{11}$ We have previously reported that ectopic administration of recombinant IGFBP-5 $(1-100 \mathrm{ng} / \mathrm{ml})$ was able to induce a proliferative effect in NB cells. ${ }^{27}$ Addition of $1 \mathrm{ng} / \mathrm{ml}$ of recombinant IGFBP-5 increased proliferation of IGFBP-5-interfered cells (clone I2B) to $112 \pm 3.87$ compared with $100 \pm 3.79$ of untreated cells (Figure $5 \mathrm{a}$ ). Administration of recombinant IGF2 $(100 \mathrm{ng} / \mathrm{ml})$ also augmented proliferation of the same cells $(114 \pm 2.52)$ (Figure $5 a)$. When cultures were treated with both IGF2 $(100 \mathrm{ng} / \mathrm{ml})$ and IGFBP-5 $(1 \mathrm{ng} / \mathrm{ml})$, there was a further increase in proliferation $(122 \pm 1.87)$ (Figure 5a). To distinguish between IGF-dependent and -independent effects of IGFBP-5 on cell proliferation, cells were incubated in the presence of an anti-IGF1R blocking antibody $(\alpha \mathrm{IR} 3)$. Treatment with $\alpha$ IR3 $(2 \mu \mathrm{g} / \mathrm{ml})$ caused a decrease in proliferation $(70 \pm 2.47)$ (Figure 5a). However, the same treatment $(\alpha \mathrm{IR} 3,2 \mu \mathrm{g} / \mathrm{ml})$ in the presence of recombinant IGFBP-5 $(1 \mathrm{ng} / \mathrm{ml})$ was less inhibitory $(87 \pm 2.24)$ (Figure $5 \mathrm{a}$ ), suggesting an IGF-independent proliferative effect of IGFBP-5.

A partial rescue of the proliferation $(84 \pm 1.60)$ was also obtained by adding recombinant IGF2 $(100 \mathrm{ng} / \mathrm{ml})$ to cells treated with $\alpha$ IR3 (Figure 5a). Simultaneous administration of recombinant IGF2 (100 ng/ml) and IGFBP-5 $(1 \mathrm{ng} / \mathrm{ml})$ to $\alpha$ IR3treated cells caused a slightly higher rescue of proliferation than single treatments $(91 \pm 1.85)$ (Figure $5 a)$. In addition,

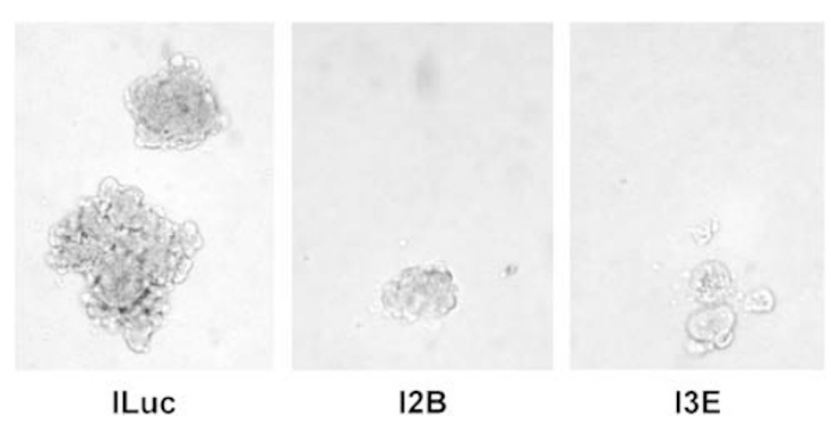

Figure 4 Growth in semisolid agar. Representative microscopic fields of controls (ILUC) and IGFBP-5-interfered clones (I2B and I3E) after staining with crystal violet (11 days in semisolid agar)

Table 2 IGFBP-5 interference reduces clonogenic activity in semisolid agar assays

\begin{tabular}{|c|c|c|c|c|c|}
\hline Name & Clones $>20$ cells & Single cells & Total cells counted & $P *$ & $\%$ Clonogenicity \\
\hline ILuc & 83 & 124 & 207 & & 40.1 \\
\hline $12 B$ & 4 & 198 & 202 & $<0.001$ & 2.0 \\
\hline $\mathrm{I} 3 \mathrm{E}$ & 38 & 173 & 211 & $<0.001$ & 18.0 \\
\hline
\end{tabular}

Cells were seeded and allowed to grow for 11 days. After staining, clones were counted as described in Materials and Methods. The \% of clonogenicity was calculated as clones/total cells $\times 100$. Statistical significance $\left(P^{*}\right)$ in comparison with the value of the ILuc control was calculated by the two-tailed Student's $t$-test 
a

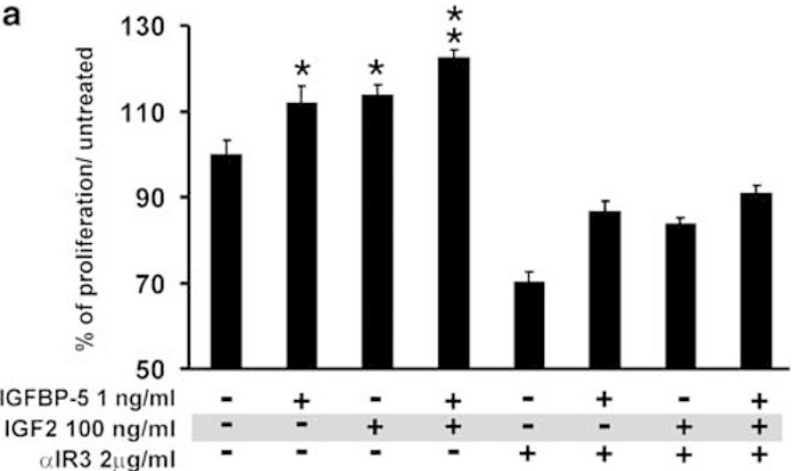

b

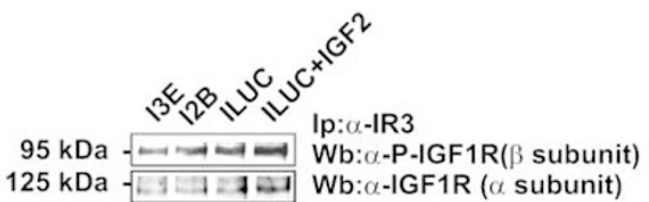

Figure 5 Effect of recombinant IGF2 and IGFBP-5 on proliferation of IGFBP-5interfered cells. (a) Cell proliferation of an IGFBP-5-interfered clone (I2B) was measured after administration of recombinant IGFBP-5 and IGF2 as indicated. When the anti-IGF1R blocking antibody ( $\alpha$ IR3) was added, cells were pretreated for $5 \mathrm{~h}$ with the antibody before adding recombinant proteins. Cells were seeded in RPMI $1640+7.5 \%$ heat-inactivated FCS, treated and assayed for proliferation $48 \mathrm{~h}$ later. Single asterisks indicate statistically significant differences in comparison with untreated cells (first column on the left). Double asterisk indicates statistically significant difference compared with columns with single asterisk. Each bar is represented \pm S.D. (b) Immunoprecipitations of IGF1R were carried out with a specific monoclonal antibody ( $\alpha \mathrm{IR} 3)$ on selected IGFBP-5interfered clones and controls (ILuC untreated and ILuC + IGF2), in standard growth conditions. Recombinant IGF2 was added $4 \mathrm{~h}$ before harvesting. Western blot analysis on the immunoprecipitates was performed with an anti-phosphoIGF1R ( $\beta$ subunit) and anti-IGF1R ( $\alpha$ subunit)

amount and autophosphorylation of IGF1R in IGFBP-5-interfered clones and controls in standard growth conditions (medium plus $10 \%$ FCS) remained essentially unchanged as detected by immunoprecipitation and Western blot analysis (Figure $5 \mathrm{~b}$ ).

\section{Increase of spontaneous apoptotic rate in IGFBP- 5-interfered cells}

The morphology of IGFBP-5-interfered cells revealed features of apoptosis such as membrane blebbing and irregular nuclear shape. Staining with Hoechst 33258 highlighted chromatin condensation and presence of vacuoli in many IGFBP-5-interfered cells from individual clones cultured in medium supplemented with $7.5 \%$ inactivated fetal calf serum for $96 \mathrm{~h}$ (data not shown). Different clones of IGFBP-5interfered cells, kept in the same culture conditions described above, were stained with propidium iodine $(\mathrm{PI})$ and subjected to flow cytometry to determine their DNA content. This experiment revealed a statistically significant increase of hypodiploid DNA (ranging from 17.82 to $40.36 \%$ ) in the IGFBP-5-interfered clones compared to the ILuc control (10.12\%) (see Table 3). The higher apoptosis of IGFBP-5interfered cells prompted us to test whether other agents could act in a agonistic manner to further enhance apoptosis. Thus, IGFBP-5-interfered and control cells were treated with two different $\mathrm{X}$-rays doses (4 and $8 \mathrm{~Gy}$ ) and caspase $3 / 7$ activation was measured by luminometric assays after
Table 3 Flow cytometric analysis of DNA content in IGFBP-5-interfered cells

\begin{tabular}{lcccc}
\hline Clone & Hypodiploid peak (\%) & G1 (\%) & S (\%) & G2/M (\%) \\
\hline ILuC & 10.12 & 73.15 & 7.89 & 9.30 \\
I2B & 40.36 & 52.06 & 2.83 & 4.89 \\
I3E & 18.62 & 65.30 & 6.52 & 9.81 \\
I3F & 17.82 & 66.31 & 6.25 & 9.79 \\
I3G & 36.22 & 53.47 & 4.10 & 6.05
\end{tabular}

DNA content of IGFBP-5-interfered and control cells was measured by propidium iodide staining followed by flow cytometric analysis. In all, $2 \times 10^{5}$ cells $/ \mathrm{cm}^{2}$ were cultured in the presence of RPMI $1640+7.5 \%$ heatinactivated FCS for $96 \mathrm{~h}$ and then cells and supernatant were collected. In all, $2 \times 10^{4}$ cells/clone were measured for their DNA content. Analysis of the data was carried out with Fast Comp program. Each phase of the cell cycle was expressed as \% of the complete cell cycle
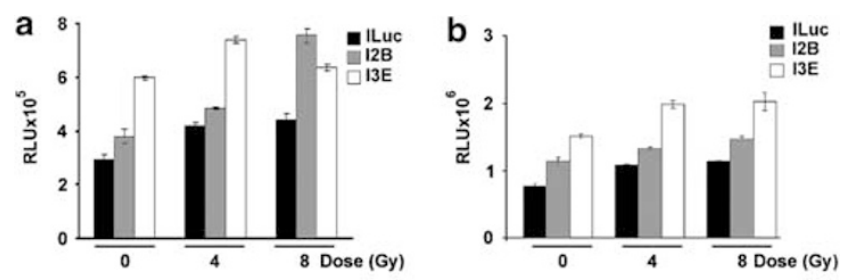

C

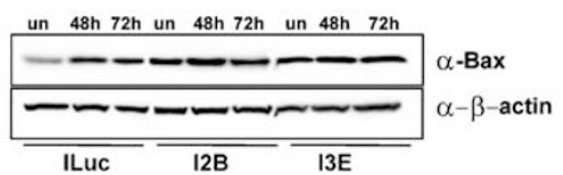

Figure 6 IGFBP-5 interference causes an increase in spontaneous apoptosis. (a and $\mathbf{b}$ ) IGFBP-5-interfered cells and controls (seeded at the initial density of $10^{4}$ cells $/ \mathrm{cm}^{2}$ in RPMI $1640+7.5 \%$ heat-inactivated FCS) were treated with two different $X$-ray doses (4 and 8 Gy) or left untreated and caspase 3/7 activity was measured 30 (Figure $6 \mathrm{a}$ ) and $72 \mathrm{~h}$ (Figure $6 \mathrm{~b}$ ) after irradiation. (c) Western blot analysis of Bax protein in IGFBP-5-interfered clones and controls was carried out in standard growth conditions (UN) (RPMI $1640+10 \%$ FCS) and after starvation $(48,72 \mathrm{~h}$ in RPMI $1640+7.5 \%$ heat-inactivated FCS $)$

irradiation ( $30 \mathrm{~h}$, Figure $6 \mathrm{a}$ and $72 \mathrm{~h}$, Figure $6 \mathrm{~b}$ ). Although the levels of active caspase $3 / 7$ increased in IGFBP-5interfered cells as well as in the controls, the former had always a higher activity, which was proportional to the X-ray dose used (Figure 6a and b), demonstrating that other proapoptotic stimuli could enhance the effects associated with IGFBP-5 inhibition. We also analyzed expression of the proapoptotic protein Bax in basal and starvation growth condition: Bax levels in the interfered clones were elevated independently from the culture conditions, while starvation was required in control cells to obtain Bax levels comparable to those of the IGFBP-5-interfered cells (Figure 6c). The induction of apoptosis upon IGFBP-5 silencing is unlikely to be a feature restricted to the LAN-5 cells, as the SY $5 Y(N)$ cell line, transfected with siRNA directed against IGFBP-5, showed a 2.6-fold increase in Bax expression compared to control by real-time PCR (Figure 3b, right panel).

\section{IGFBP-5 interference affects the differentiation competence of NB cells}

LAN-5 cells differentiate toward a neuronal phenotype and exhibit increased IGFBP-5 expression when treated with alltrans-retinoic acid (RA) at micromolar concentrations. ${ }^{28} \mathrm{We}$ 
tested the behavior of RA-treated IGFBP-5-interfered cells in comparison with controls in the same culture conditions. After 3 days of RA treatment $(5 \mu \mathrm{M})$, an intricate net of neurites outgrew and the cell body became elongated in control cells (Figure 7, compare a to d), while IGFBP-5-interfered cells became larger and flat with absent (Figure 7 compare b to e) or few neurites (Figure 7 compare $c$ to $f$ ). In muscle cells, the simultaneous administration of IGF1 and IGFBP-5 (100 ng/ $\mathrm{ml}$ ) was able to promote differentiation. ${ }^{38}$ Interestingly, when the same amount of recombinant IGFBP-5 $(100 \mathrm{ng} / \mathrm{ml})$ was added to the cultures together with RA, IGFBP-5-interfered cells reacquired the ability to differentiate indistinguishably from controls (Figure 7, $\mathrm{h}$ and i compared to $\mathrm{g}$ ). Of note, a similar effect was obtained also with lower amounts of IGFBP$5(1 \mathrm{ng} / \mathrm{ml})$ although to a lesser extent (not shown). To assess whether the effect of IGFBP-5 on cell differentiation of NB cells was dependent on IGF1R signaling, LAN-5 cells were

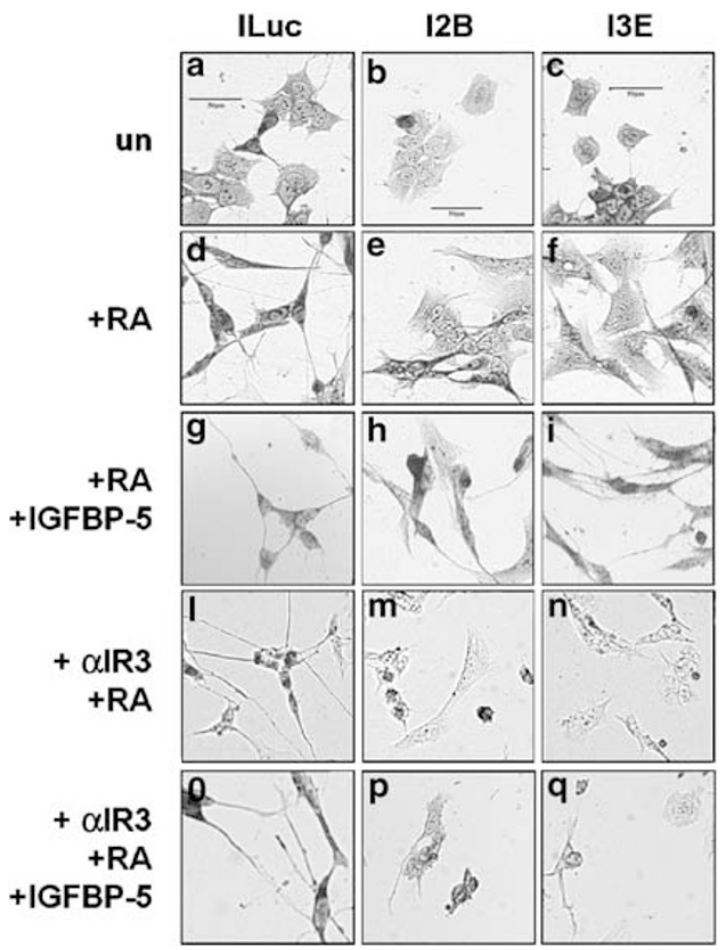

Figure 7 Effect of IGFBP-5 interference on neuronal differentiation of LAN-5 cells. Control ( $a, d, g, l, 0)$ and IGFBP-5-interfered cells (b, e, h, m, p and c, f, i, n, q) stained with methylene blue in different conditions: untreated (a, b, c), treated with RA $(5 \mu \mathrm{M})$ for 3 days $(\mathrm{d}, \mathrm{e}, \mathrm{f})$, treated with $\mathrm{RA}+100 \mathrm{ng} / \mathrm{ml}$ IGFBP- $5(\mathrm{~g}, \mathrm{~h}, \mathrm{i})$, pretreated with $\alpha \mathrm{IR} 3$ for $5 \mathrm{~h}$ and treated with $\mathrm{RA}(\mathrm{I}, \mathrm{m}, \mathrm{n})$, pretreated with $\alpha \mathrm{IR} 3$ for $5 \mathrm{~h}$ before adding RA $+100 \mathrm{ng} / \mathrm{ml} \operatorname{IGFBP}-5(0, p, q)$ pretreated with the IGF1R blocking antibody $\alpha$ IR3 $(2 \mu \mathrm{g} / \mathrm{ml})$ followed by the administration of RA alone (Figure 7I, $m, n$ ) or in combination with IGFBP-5 (Figure 7o, p, q). IGFBP-5interfered cells were unable to differentiate toward a neuronal phenotype and underwent cell death when IGF1R was blocked by $\alpha \mathrm{IR} 3$ antibody (compare panels $\mathrm{m}$ and $\mathrm{n}$ with I). The ability to differentiate was only partially rescued by addition of IGFBP-5 to cells treated with $\alpha$ IR3 antibody and $\mathrm{RA}$, although a large number of IGFBP-5-interfered cells still underwent cell death (Figure $7, p$ and $q$ compared with o). A quantitative evaluation of apoptosis and differentiation in these culture conditions is presented in Table 4. Cells were defined as apoptotic when their nucleus was pycnotic and cytoplasm was scarce or absent. Cells were defined differentiated when neurites outgrowth exceeded twice the length of the cell body. In control cells, $5.86 \%$ were scored as apoptotic compared with 23.94 and $17.32 \%$ in I2B and I3E IGFBP-5-interfered cells, respectively. Differentiated cells were $86.79 \%$ in control (ILUC) as compared with 58.03 and $64.84 \%$ in I2B and I3E IGFBP-5-interfered cells, respectively. It should be noted that the actual degree of cell death is underestimated in the panels of Figure 7, since most dead cells were floating in the medium and were lost during the staining process.

In addition, we assessed the presence of a classical neuronal marker, neurofilaments, in cells treated with RA for different times. Compared with controls (ILUC), levels of neurofilaments were low or undetectable in IGFBP-5-interfered cells (Figure 8a). Interestingly, another intermediate filament protein, vimentin, showed multiple bands only in IGFBP-5-interfered cells (Figure 8a). Since vimentin is proteolytically cleaved by different caspases, ${ }^{39}$ this observation is consistent with the activation of apoptosis in RA-treated IGFBP-5-interfered cells. In agreement with the effects on morphological differentiation (Figure 7), treatment with recombinant IGFBP-5 (100 ng/ml) induced an increase of NF expression after 3 days of RA treatment (Figure $8 \mathrm{~b}$ ). In the same culture conditions, the control cells expressed a much higher level of NF (Figure 8b). In contrast, the level of vimentin in the IGFBP-5-interfered clones was higher than in control (Figure 8b).

\section{Discussion}

Three components of the IGF axis, IGFBP $-5,{ }^{28}$ IGF2 and IGF $1 R^{40}$, are readily expressed in NB cells, but the significance of IGFBP-5 remains unclear. We used micro RNA producing vectors and small interfering RNA to inhibit the

Table 4 Effect of RA $(5 \mu \mathrm{M})$ and IGFBP-5 $(100 \mathrm{ng} / \mathrm{ml})$ treatment in IGFBP-5-interfered and control cells pretreated with anti-IGFIR blocking antibody $(2 \mu \mathrm{g} / \mathrm{ml})$

\begin{tabular}{lcccc}
\hline Clone & $\begin{array}{c}\text { Differentiated cells } \\
\text { (number and \%) }\end{array}$ & $\begin{array}{c}\text { Undifferentiated cells } \\
\text { (number and \%) }\end{array}$ & $\begin{array}{c}\text { Apoptotic cells } \\
\text { (number and \%) }\end{array}$ & $\begin{array}{c}\text { Total cells counted } \\
\boldsymbol{P}^{*}\end{array}$ \\
\hline ILUC & $874(86.79 \%)$ & $74(7.35 \%)$ & $59(5.86 \%)$ & 1007 \\
I2B & $589(58.03 \%)$ & $183(18.03 \%)$ & $243^{*}(23.94 \%)$ & 1015 \\
I3E & $745(64.84 \%)$ & $205(17.84 \%)$ & $199^{*}(17.32 \%)$ & 1149
\end{tabular}

Experiments were repeated twice with comparable results: results are representative of one experiment. After treatment, cells were fixed and stained with methylene blue. More then 1000 cells were counted in each experiment. ${ }^{*} P$ represents the statistical significance of the differences in the number of apoptotic cells between control (ILUC) and IGFBP-5-interfered cells (I2B and I3E) calculated by $\chi^{2}$ method 
a

$$
+ \text { RA }
$$

UN 1d 3d $6 d$ UN 1d $3 d \quad 6 d$

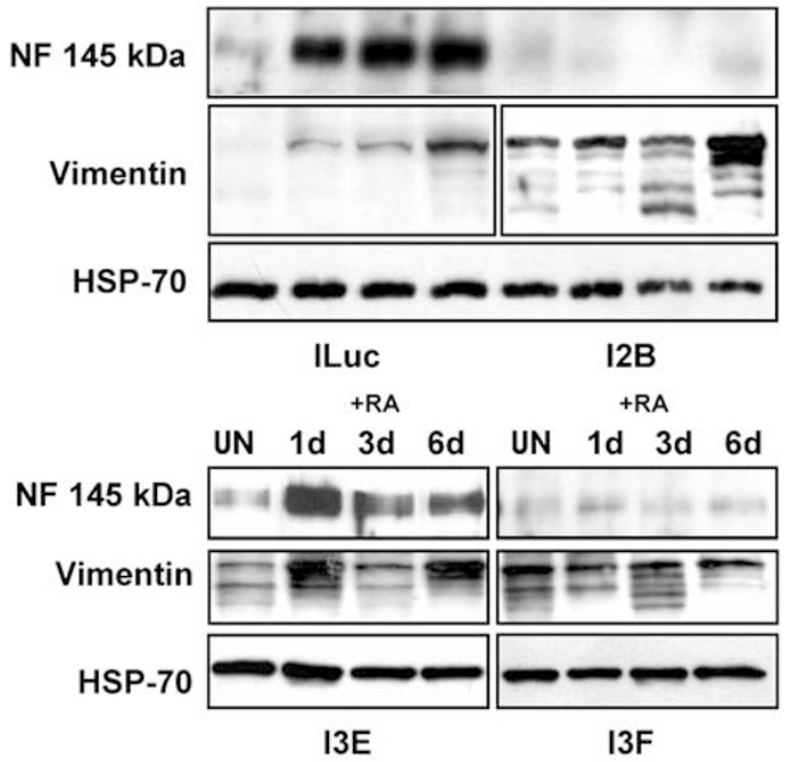

b

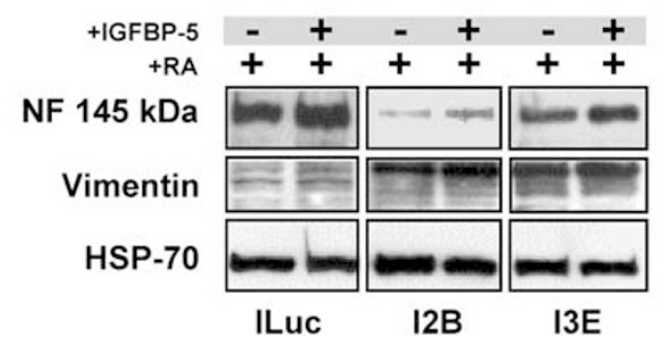

Figure 8 (a) Western blot analysis of untreated and RA-treated $(5 \mu \mathrm{M})(1,3$ and 6 days) controls and IGFBP-5-interfered clones. Blots were probed with antineurofilament $145 \mathrm{kDa}$, anti-vimentin and anti-HSP-70 antibodies. (b) Detection of NF $145 \mathrm{kDa}$ and vimentin in cells treated with RA ( $5 \mathrm{mM})$ and RA + IGFBP-5 $(100 \mathrm{ng} / \mathrm{ml})$ for 3 days

endogenous expression of IGFBP-5 in NB cells. Although we could achieve a substantial reduction of IGFBP-5 both in the intracellular and in the extracellular compartments, we were unable to ablate protein expression completely in selected clones. Of note, during antibiotic selection many clones did not survive, suggesting that complete inhibition of IGFBP-5 in NB cells was incompatible with survival. Nevertheless, even a reduction of the IGFBP-5 synthesis caused several effects on proliferation, apoptosis and differentiation.

Previous data from our laboratory demonstrated that administration of recombinant IGFBP-5 had a biphasic effect: low-moderate concentrations of IGFBP-5 evoked a moderate proliferative response; higher amounts caused growth inhibition. ${ }^{27}$ Different clones of IGFBP-5-interfered cells had a substantial reduction of proliferation, which suggests a growth promotion activity of the endogenously expressed IGFBP-5 in NB cells. Our data demonstrated also that IGF2 and IGFBP-5 were both able to stimulate growth in IGFBP-5-interfered cells and controls. Of interest, although IGF2 RNA levels were increased in IGFBP-5-interfered cells, the amount of protein in the culture supernatants did not show relevant differences compared to control. This could be due to a post-transcrip- tional regulation of IGF2 that prevents the synthesis of high amounts of IGF2. In normal growth conditions, phosphorylation of the IGF1R receptor was unchanged in IGFBP-5interfered cells compared with controls although IGF1R receptor phosphorylation can be further increased upon addition of recombinant IGF2. This finding suggests that the effect of IGFBP-5 interference on cell proliferation could be due to an IGF-independent activity of IGFBP-5. This hypothesis is further supported by the observation that administration of ectopic IGFBP-5 to cells in which the IGF1R receptor was blocked with the $\alpha \mathrm{IR} 3$ antibody stimulated growth. Culturing the IGFBP-5-interfered NB cells in the presence of both IGF2 and IGFBP-5 evoked a higher proliferative effect than that obtained by each protein alone. In conclusion, although our data confirm that IGF2 stimulates proliferation of NB cells, they suggest that endogenously produced IGFBP-5 acts, at least in part, via an IGF-independent mechanism, consistent with the effect of IGFBP-5 in stimulating proliferation of bone cells. ${ }^{11}$ The activity of IGFBP-5 as a growth stimulatory protein was also demonstrated in smooth muscle cells. ${ }^{41}$ On the contrary, the proliferation of mammary cells transfected or infected with vectors producing IGFBP-5 was inhibited. ${ }^{16}$ The proliferation-promoting effect of the endogenously produced IGFBP- 5 in NB cells supports the notion that this protein can achieve apposite effects in different cell types, which may depend on the availability of other components of the IGF axis. In NB, it is likely that balanced amounts of different endogenously produced IGF axis components act together to achieve the best conditions for proliferation of these tumor cells. Thus, altering this equilibrium by inhibiting IGFBP-5 expression has a detrimental effect on proliferation. IGFBP-5-interfered NB cells exhibited also a decreased ability to grow in anchorage-independent conditions, a feature which is a hallmark of a fully transformed phenotype. ${ }^{42}$ Consistent with the reduced proliferation of IGFBP-5-interfered cells, clones formed from these cells, plated in semisolid medium, were invariably smaller than those of controls.

In parallel with the reduced proliferation, IGFBP-5-interfered cells had an increased propensity to undergo apoptosis either spontaneously or upon nutrient deprivation. The apoptotic process was clearly demonstrated by an increase in the hypodiploid DNA content, activation of caspases 3 and 7 and increased Bax protein levels. Interestingly, fragmentation of vimentin, a known caspase target, ${ }^{39}$ was detectable only in IGFBP-5-interfered cells in differentiating conditions. Thus, the main consequence of IGFBP-5 inhibition was to prevent neuronal maturation (see below), and to drive the cells toward apoptosis in the presence of a differentiation inducer. The increased propensity to undergo apoptosis was associated with augmented expression of Bax. Although the mechanism of this event remains unclear, Bax overexpression is expected to promote changes in mitochondrial permeability causing a release of proapoptotic molecules. ${ }^{43}$ In tumors, forcing the cells to undergo apoptosis is a relatively new but potentially effective therapeutic strategy. ${ }^{44}$ Our finding on the increased apoptosis susceptibility of IGFBP-5-interfered NB cells prompted us to assess whether this propensity could be exploited to enhance the proapoptotic effects of ionizing radiations. Although there was no synergism between IGFBP5 inhibition and irradiation, we could achieve an additive effect 
that was proportional to the X-ray dose. This could possibly be due to the proapoptotic activities of ionizing radiations and IGFBP-5 inhibition involving different mediators of the same pathway, although an effect via parallel or distinct pathways cannot be excluded. Nevertheless, the increased apoptotic susceptibility of IGFBP-5-interfered cells upon X-ray irradiation points toward future therapeutic applications in NB and in other IGFBP-5-expressing tumors.

The expression of IGFBP-5 increases during NB differentiation, ${ }^{28}$ suggesting a role for this protein also during this process. We found that IGFBP-5 interference strongly impaired the ability of NB cells to undergo neuronal differentiation as confirmed by lack of neurite outgrowth and neurofilaments expression after 3 days of RA treatment, although we cannot rule out the switching to other differentiation lineages. The fragmentation of vimentin observed in RAtreated IGFBP-5-interfered cells suggests that, during differentiation, these cells were more prone to apoptosis than control cells. The impairment of neuronal differentiation was partially reversed by administration of recombinant IGFBP-5. Thus, the presence of optimal IGFBP-5 levels is a requisite for neuronal differentiation of NB cells. This finding is consistent with data obtained in other cell systems where activation of IGF axis occurs during differentiation, ${ }^{45}$ and with the reported increase of IGF1 expression during neuronal differentiation. ${ }^{46}$ In addition, IGF2 and IGFBP-5 increased during RA-induced differentiation in LAN-5 cells. ${ }^{28}$ When IGF1R was blocked by a specific antibody, treatment of the cells with RA and recombinant IGFBP-5 caused a significant neuronal differentiation in parallel with the appearance of numerous pycnotic cells consistent with further increase of apoptosis. Together, these data indicate that IGFBP-5 has a significant effect on the ability of NB cells to undergo neuronal differentiation and also that the activity of the IGF signal transduction is required to protect the cells from undergoing apoptosis in the presence of differentiation-inducing stimuli. Preliminary data indicated that also neural differentiation induced with CAMP was impaired in IGFBP-5-interfered clones (not shown), suggesting that the involvement of IGFBP-5 in the differentiation process is not limited to a single inducer.

In conclusion, inhibition of endogenous expression of IGFBP-5 by means of micro and small interfering RNA has marked effects on proliferation, apoptosis and differentiation of NB cells. The inhibition of proliferation associated with increased susceptibility to apoptosis makes IGFBP-5 protein a promising target for a biological approach to NB therapy.

\section{Materials and Methods}

\section{Expression plasmids for micro RNA production}

The pMIREV plasmid (Micro Interfering RNAs Expressing Vector) was engineered to transcribe hairpin RNAs from human U6 promoter (265 bp upstream the transcription start) ${ }^{32}$ and to contain resistance to puromycin. The promoter of human U6 gene was obtained by PCR from human DNA and cloned in the Kpnl/Smal sites of the pBluescript SK vector. The cassette containing the SV-40 minimum promoter and the puromycin resistance gene was subcloned from plasmid pBabe-puro into the Sapl site of pBluescript SK-U6 using standard techniques. The resulting vector was named pMIREV. Three different target sequences identified as 1, 2 and 3 and located at the $3^{\prime}$ UTR of the human IGFBP-5 mRNAs were selected using a program (RNAi OligoRetriever, http://www.cshl.edu/ public/SCIENCE/hannon.html) designed to identify optimal regions for interference by micro RNAs. The corresponding DNA sequences that can be transcribed in hairpin RNAs were: I1 strand + : 5'-GGGCTGGGGG TGGGAGGGGGTGAGGGAAGAAGCTTGTTCCTTCGCCCCCTCCCAC TCCCAGTCCCGATTTTTTTCTAGACTAGG-3', strand-: 5' - CCTAGTCT AGAAAAAATCGGGACTGGGAGTGGGAGGGGGCGAAGGAACAAG CTTCTTCCСTCACCСССTCCCACCCCCAGCCC-3'; 12 strand + : $5^{\prime}-\mathrm{G}$ GGAGAGACAACACTCTGCCCAGGTAAGGAAGCTTGCTTATCTGGGT AGGGTGTTGTCTCTTCCCAATTTTTTTCTAGACTAGG-3', strand-: $5^{\prime}$-C CTAGTCTAGAAAAAAATTGGGAAGAGACAACACCCTACCCAGATAA GCAAGCTTCCTTACCTGGGCAGAGTGTTGTCTCTCCC -3 '; 13 strand + : 5'-GTCTCGGTGCATGTCCTTCCTGCCCACCGAAGCTTGGGTGGGCG GGGAGGACGAGTACCGAGACCAGTTTITTCTAGACTAGG-3', strand-: 5'-CCTAGTCTAGAAAAAAACTGGTCTCGGTACACGTCCTCCCCGCC CACCCAAGCTTCGGTGGGCAGGAAGGACATGCACCGAGAC-3'; ILuc strand + : 5'GGATTCCAATTCAGCGGGAGCCACCTGATGAAGCTTG ATCGGGTGGCTCTCGCTGAGTTGGAATCCATTTTTTTCTAGACTAG G-3', strand-: 5'-CCTAGTCTAGAAAAAAATGGATTCCAACTCAGCGA GAGCCACCCGATCAAGCTTCATCAGGTGGCTCCCGCTGAATTGGAA TCC-3'. I1, I2 and I3 double-stranded oligonucleotides were cloned in the Smal site of pMIREV vector to generate PMIREV I1, pMIREV 12 and pMIREV I3. ILuc double-stranded oligonucleotides that were previously demonstrated to produce micro RNA inhibiting firefly luciferase ${ }^{33}$ were similarly cloned to generate pMIREV ILuc.

\section{RNA interference with small interfering RNA}

Three sequences in the $3^{\prime}$ untranslated region of the human IGFBP-5 mRNA were chosen as targets for RNA interference. The corresponding primers to obtain small interfering RNA with the Silencer ${ }^{\mathrm{TM}}$ siRNA construction kit cat \# 1620 (Ambion, Austin, TX, USA) were as follows: A: sense 5'-AAACGGGAGTCTCTCTCGATCCCTGTCTC-3', antisense 5'AAGATCGAGAGAGACTCCCGTCCTGTCTC-3'; B: sense 5'-AAGAATC CTTTGCGGTCACAACCTGTCTC-3', antisense 5'-AATTGTGACCGCAA AGGATTCCCTGTCTC-3'; C: sense 5'-AACTTCTTTCTGCGGTCCTT CCCTGTCTC-3' ${ }^{\prime}$, antisense 5'-AAGAAGGACCGCAGAAAGAAGCCTGT CTC-3'. Small interfering RNAs were produced according to the manufacturer's instructions. Transfections into $S Y 5 Y(N)$ cells were carried out using Lipofectamine 2000 (Invitrogen Corporation, Carlsbad, CA, USA) as previously described. ${ }^{36}$

\section{Cell culture and transfections}

The NB cell line LAN $-5^{47}$ was cultured in RPMI 1640 medium (Euroclone, Paignton, Devon, UK) supplemented with $10 \%$ fetal calf serum (Hyclone, Logan, UT, USA), penicillin and streptomycin (100 $\mu \mathrm{g} / \mathrm{ml}$ each), and $2 \mathrm{mM}$ L-glutamine at $37^{\circ} \mathrm{C}, 5 \% \mathrm{CO}_{2}$. The $\mathrm{NB}$ cell line $\mathrm{SY} 5 \mathrm{Y}(\mathrm{N})^{36}$ was cultured in D-MEM (Euroclone, Paignton, Devon, UK) supplemented with $10 \%$ fetal calf serum (Hyclone, Logan, UT, USA), penicillin and streptomycin $\left(100 \mu \mathrm{g} / \mathrm{ml}\right.$ each), and $2 \mathrm{mM}$ L-glutamine at $37^{\circ} \mathrm{C}, 5 \% \quad \mathrm{CO}_{2}$. In differentiation assays, all-trans-RA (SIGMA, Saint Louis, MO, USA) was used at the final concentration of $5 \mu \mathrm{M}$ as previously described. ${ }^{48}$ Medium containing RA was changed every 3 days. For stable transfections, LAN- 5 cells grown at $70 \%$ confluence were transfected with the expression vectors (pMIREV I1, pMIREV I2 and pMIREV I3), which transcribe hairpin RNAs processed in the cells to become micro RNAs and the control pMIREV ILuc, using the calcium phosphate precipitation technique as described previously. ${ }^{47}$ Puromycin (SIGMA) selection $(1 \mu \mathrm{g} / \mathrm{ml})$ was 
started $48 \mathrm{~h}$ after transfection. Single clones were expanded for 28 days and tested for IGFBP-5 expression.

\section{Semisolid agar assays}

Anchorage-independent growth was carried out in semisolid agar as follows: base agar (0.5\%. agar, $1 \times$ RPMl 1640 and 10\% fetal calf serum) was added in each well and allowed to solidify; an equal volume of top agar $(0.35 \%$ agar, $1 \times$ RPMl 1640 and $10 \%$ fetal calf serum) in which cells were present at the concentration of $10^{3} \mathrm{cells} / \mathrm{cm}^{2}$ was added in the same well. Plates were incubated at $37^{\circ} \mathrm{C}, 5 \% \mathrm{CO}_{2}$ in a humidified incubator for 11 days and stained with $0.005 \%$ crystal violet for $>1 \mathrm{~h}$. Single cells (defined as cells or aggregates of $<20$ cells) and clones (aggregates of $>20$ cells) were scored in the plates counting at least 200 elements in each plate. Each experimental point was carried out in duplicate. Experiments were repeated twice with overlapping results.

\section{Proliferation assays}

Cells were seeded at a density of $4 \times 10^{4} / \mathrm{cm}^{2}$ in RPMl 1640 medium supplemented with $10 \%$ fetal calf serum and counted at different times. Doubling times were calculated using the following equation: $\mathrm{Dt}=\Delta \mathrm{t} /$ $\log _{2}(C 1 / C 0)$ where $D t$ is the doubling time, $\Delta t$ is the difference between ending and starting time, and $C 1$ and $C O$ are the cell counts at the ending and starting times, respectively. Cell proliferation/viability was measured using the WST-1 kit (Roche Molecular Biochemicals, Mannheim, Germany) based on the colorimetric detection of a formazan salt. In each well, $4 \times 10^{4}$ cells were seeded in RPMl 1640 medium supplemented with $7.5 \%$ heat-inactivated fetal calf serum. Recombinant IGFBP-5 (Upstate Biotechnology, Inc. Charlottesville, VA, USA), IGF2 (SIGMA), and blocking antibody to IGF1R ( $\alpha$ IR3, Oncogene, Research, San Diego, CA, USA) were added at the indicated concentration, and the colorimetric reading at $450 \mathrm{~nm}$ was carried out after $48,72 \mathrm{~h}$ according to the manufacturer's instructions. Background absorbance of each sample at $630 \mathrm{~nm}$ was subtracted from the readings at $450 \mathrm{~nm}$.

\section{Apoptosis}

Evaluation of DNA content was carried out with propidium iodide staining $(50 \mu \mathrm{g} / \mathrm{ml})$ followed by flow cytometric analysis (FACSCalibur, Becton Dickinson, Bedford, MA, USA).

Caspase 3 and 7 activities were measured using the luminescent Caspase-Glo ${ }^{\mathrm{TM}} 3 / 7$ kit (Promega, Madison, WI, USA) based on detection of a luminescent caspase $3 / 7$ substrate following caspase cleavage. In each well, $1.5 \times 10^{4}$ cells were seeded in RPMl 1640 medium supplemented with $7.5 \%$ heat-inactivated fetal calf serum. Cells were irradiated with 4 and 8 Gy using a Gilardoni X-ray generator (Gilardoni S.p.A., Mandello del Lario, Lecco, Italy) and the Caspase-Glo assays were carried out 30 or $72 \mathrm{~h}$ later according to the manufacturer's instructions.

\section{Protein analysis: Western blots and immunoprecipitations}

Cellular proteins were extracted as described previously. ${ }^{48}$ Immunoprecipitation was carried out as follows: $500 \mu \mathrm{g}$ of cellular extract was preincubated with protein G-Sepharose beads (Pharmacia, Biotec. Uppsala, Sweden) for $45 \mathrm{~min}$ at $4^{\circ} \mathrm{C}$. The supernatant was incubated with protein G-Sepharose beads coated with IGF1R ( $\alpha \mathrm{IR} 3$ )-specific antibody (Oncogene) overnight at $4^{\circ} \mathrm{C}$. Beads were washed four times with the immunoprecipitation buffer (50 mM Tris- $\mathrm{HCl}$ pH 7.4, $5 \mathrm{mM}$ EDTA, $250 \mathrm{mM} \mathrm{NaCl}, 50 \mathrm{mM} \mathrm{NaF}, 0.1 \%$ Triton X-100, $0.1 \mathrm{mM} \mathrm{Na}_{3} \mathrm{VO}_{4}, 1 \mathrm{mM}$ phenylmethylsulfonyl fluoride and $10 \mu \mathrm{g} / \mathrm{ml}$ leupeptin). In all, $2 \times$ SDS gelloading buffer (100 mM Tris- $\mathrm{HCl} \mathrm{pH} 6.8,200 \mathrm{mM} \mathrm{DTT}, 4 \%$ SDS, $0.2 \%$ bromophenol blue, $20 \%$ glycerol) was added directly on the protein GSepharose beads that were boiled for $5 \mathrm{~min}$. Protein extraction from the culture supernatants was carried out as described previously. ${ }^{27}$ Briefly, cells were kept for $40 \mathrm{~h}$ in serum-free medium, the supernatant was collected, supplemented with $1 \mathrm{mM}$ phenylmethylsulfonyl fluoride, $10 \mu \mathrm{g} /$ $\mathrm{ml}$ leupeptin and $10 \mu \mathrm{g} / \mathrm{ml}$ aprotinin and centrifuged for $10 \mathrm{~min}$ at $1500 \times \mathrm{g}$ at $4^{\circ} \mathrm{C}$. The supernatant was transferred to a Centricon 10 (Amicon, Millipore Corp. Bedford, MA, USA) and concentrated according to the manufacturer's instructions. Protein separation on SDS-polyacrylamide gels and Western blot analysis were carried out as described previously. ${ }^{48}$ Antibodies used were anti-IGFBP-5 (c-18) from Santa Cruz Biotechnology (Santa Cruz, CA, USA), anti- $\beta$-actin (AC-15) from SIGMA, anti-NF-M $(145 \mathrm{kDa})$ and anti-vimentin (AB1620) from Chemicon Int (Temecula, CA, USA), anti-Hsp70 (SPA-820) from StressGen Biotechnology Corp (Victoria, BC, Canada), anti-IGF1R ( $\alpha \mathrm{IR} 3, \mathrm{Ab}-1)$ from Oncogene Research, anti-IGF1R ( $\alpha$ subunit, clone 24-57) and anti-phospholGF1R (IR/IGF1R pYpYpY ${ }^{1158 / 1162 / 1163)}$ ) from Biosource Int. (Camarillo, CA, USA).

\section{ELISA test}

The ELISA test to determine IGF2 protein concentration in culture supernatants was carried out using the nonextraction IGF2 ELISA kit DSL10-2600 (Diagnostic Systems Laboratories, Webster, TX, USA) according to the manufacturer's instructions.

\section{RNA extraction RT-PCR and real-time PCR}

Total RNA was prepared using RNAwiz (Ambion). RNA was cleaned from carry-over DNA contaminations using the DNA-free kit (Ambion) and it was reverse transcribed with RETROscript kit (Ambion) according to the manufacturer's instructions. An input of $500 \mathrm{ng}$ of RNA was used for each reaction. Subsequent PCR were carried out for the indicated number of cycles at the appropriate annealing temperature for each of the following pairs of primers: OAS1: UP 5'-AGGTGGTAAAGGGTGGCTCC-3', DW 5'CAGGCAGCACATCGAACTCC-3'; IGFBP-1: UP $5^{\prime}$-GAGCCCTGCCGAATAGAACTC-3', DW 5' -TTGCAGTTTGGCAGGTAAAATTT-3'; IGFBP-2: UP 5'-TGACAAGCATGGCCTGTACAA-3', DW 5'-GGATCAGCTTCCCGGTGTT-3'; IGFBP-3: UP 5'-TGGTCCCTGCCGTAGAGAAA-3', DW 5'-CCTTCTTGTCACAGTTGGGAATG-3'; IGFBP-4: UP 5'TGCAGCCCTCTGACAAGGA-3', DW 5'-CGAATTTTGGCGAAGTGCTT3'; IGFBP-6: UP 5'-ATTCTGCGGGTGTCCAAGAC-3', DW 5'-TGT TTGAGCCCCTCGGTAGA-3'; $\beta$-actin: UP $5^{\prime}$-TCATCACCATTGGCAAT GAG-3', DW 5'-CACTGTGTTGGCGTACAGGT-3'. Real-time PCR was carried out using an ABI PRISM ${ }^{\circledR} 7000$ Sequence Detection System (Applied Biosystems, Foster City, CA, USA). TAQMAN ${ }^{\mathbb{R}}$ technology and the Assays-On-Demand (TM) kit (Hs00171254-m1) for human IGF2 were used. TAQMAN ${ }^{\circledR}$ predeveloped kit part \#4326315E for the human $\beta$-actin was used to normalize. SYBR ${ }^{\circledR}$ Green technology (SYBR ${ }^{\circledR}$ Green PCR master mix, Applied Biosystems, Foster City, CA, USA) was used to detect Cyclin D1, Bax, IGFBP-5 and $\beta$-actin to normalize. The corresponding primers for each PCR were: Cyclin D1: UP $5^{\prime}$-GCTGGCCATGAAC TACCTGG-3', DW 5'-TCTTAGAGGCCACGAACATGC-3'; Bax: UP 5'CACAGACTCCCCCCGAGAG-3', DW 5'-TGGCAAAGTAGAAAAGGG CG-3'; IGFBP-5: UP 5'-GCTACCGCGAGCAAGTCAAG-3', DW 5'GAGATGCGGGTGTGTTTGG-3'; $\beta$-actin: UP $5^{\prime}$-CCTTCAACACCC 
CAGCCA-3', DW 5'-ACCCCTCGTAGATGGGCAC-3'. Real-time PCR was performed in both simplex and duplex mode achieving overlapping results.

\section{Acknowledgements}

This work was partially supported by the Italian Association for Cancer Research (AIRC), the Foundation against Neuroblastoma (Fondazione $\mathrm{NB}$ ) and Ricerca Finalizzata Paediatric Hospital Bambino Gesù (OPBG). Vincenzo Cesi is a fellow of the Associazione NB. Roberta Vitali and Maria Laura Giuffrida are recipients of fellowships of the Paediatric Hospital Bambino Gesù (OPBG). BC is supported by grants of the National Institutes of Health.

\section{References}

1. Jones Jl and Clemmons DR (1995) Insulin-like growth factors and their binding proteins: biological actions. Endocr. Rev. 16: 3-34

2. Baserga R, Hongo A, Rubini M, Prisco M and Valentinis B (1997) The IGFreceptor in cell growth, transformation and apoptosis. Biochim. Biophys. Acta 1332: F105-F126

3. Allan GJ, Flint DJ and Patel K (2001) Insulin-like growth factor axis during embryonic development. Reproduction 122: 31-39

4. Isgaard J, Tivesten A, Friberg P and Bengtsson BA (1999) The role of the GH/ IGF-I axis for cardiac function and structure. Horm. Metab. Res. 31: 50-54

5. Anlar B, Sullivan KA and Feldman EL (1999) Insulin-like growth factor-I and central nervous system development. Horm. Metab. Res. 31: 120-125

6. Liu JP, Baker J, Perkins AS, Robertson EJ and Efstratiadis A (1993) Mice carrying null mutations of the genes encoding insulin-like growth factor I (Igf-1) and type 1 IGF receptor (Igf1r). Cell 75: 59-72

7. Coolican SA, Samuel DS, Ewton DZ, McWade FJ and Florini JR (1997) The mitogenic and myogenic actions of insulin-like growth factors utilize distinct signaling pathways. J. Biol. Chem. 272: 6653-6662

8. Clemmons DR (1998) Role of insulin-like growth factor binding proteins in controlling IGF actions. Mol. Cell Endocrinol. 140: 19-24

9. Booth BA, Boes M, Andress DL, Dake BL, Kiefer MC, Maack C, Linhardt RJ, Bar K, Caldwell EE and Weiler J (1995) IGFBP-3 and IGFBP-5 association with endothelial cells: role of C-terminal heparin binding domain. Growth Regul. 5: 1-17

10. Parker A, Clarke JB, Busby Jr WH and Clemmons DR (1996) Identification of the extracellular matrix binding sites for insulin-like growth factor-binding protein 5. J. Biol. Chem. 271: 13523-13529

11. Miyakoshi N, Richman C, Kasukawa Y, Linkhart TA, Baylink DJ and Mohan S (2001) Evidence that IGF-binding protein-5 functions as a growth factor. J. Clin. Invest. 107: 73-81

12. Duan $C$ and Clemmons DR (1998) Differential expression and biological effects of insulin-like growth factor-binding protein- 4 and -5 in vascular smooth muscle cells. J. Biol. Chem. 273: 16836-16842

13. Kuemmerle JF and Zhou H (2002) Insulin-like growth factor-binding protein-5 (IGFBP-5) stimulates growth and IGF-I secretion in human intestinal smooth muscle by Ras-dependent activation of p38 MAP kinase and Erk1/2 pathways. J. Biol. Chem. 277: 20563-20571

14. Chan TW, Pollak M and Huynh $\mathrm{H}$ (2001) Inhibition of insulin-like growth factor signaling pathways in mammary gland by pure antiestrogen $\mathrm{ICI} 182,780$. Clin. Cancer Res. 7: 2545-2554

15. Flint DJ, Tonner E and Allan GJ (2000) Insulin-like growth factor binding proteins: IGF-dependent and -independent effects in the mammary gland. J. Mammary Gland Biol. Neoplasia 5: 65-73

16. Butt AJ, Dickson KA, McDougall F and Baxter RC (2003) Insulin-like growth factor-binding protein- 5 inhibits the growth of human breast cancer cells in vitro and in vivo. J. Biol. Chem. 278: 29676-29685

17. Nickerson T, Pollak M and Huynh H (1998) Castration-induced apoptosis in the rat ventral prostate is associated with increased expression of genes encoding insulin-like growth factor binding proteins 2,3,4 and 5. Endocrinology 139: $807-810$
18. Tonner E, Barber MC, Allan GJ, Beattie J, Webster J, Whitelaw CB and Flint DJ (2002) Insulin-like growth factor binding protein-5 (IGFBP-5) induces premature cell death in the mammary glands of transgenic mice. Development 129 : 4547-4557

19. Beilharz EJ, Klempt ND, Klempt M, Sirimanne E, Dragunow M and Gluckman PD (1993) Differential expression of insulin-like growth factor binding proteins (IGFBP) 4 and 5 mRNA in the rat brain after transient hypoxic-ischemic injury. Brain Res. Mol. Brain Res. 18: 209-215

20. Perks CM, Bowen S, Gill ZP, Newcomb PV and Holly JM (1999) Differential IGF-independent effects of insulin-like growth factor binding proteins (1-6) on apoptosis of breast epithelial cells. J. Cell Biochem. 75: 652-664

21. Roschier M, Kuusisto E, Suuronen T, Korhonen P, Kyrylenko S and Salminen A (2001) Insulin-like growth factor binding protein 5 and type-1 insulin-like growth factor receptor are differentially regulated during apoptosis in cerebellar granule cells. J. Neurochem. 76: 11-20

22. LeRoith D and Roberts Jr CT (2003) The insulin-like growth factor system and cancer. Cancer Lett. 195: 127-137

23. Baserga R, Peruzzi F and Reiss K (2003) The IGF-1 receptor in cancer biology. Int. J. Cancer 107: 873-877

24. El Badry OM, Helman LJ, Chatten J, Steinberg SM, Evans AE and Israel MA (1991) Insulin-like growth factor II-mediated proliferation of human neuroblastoma. J. Clin. Invest. 87: 648-657

25. Brodeur GM (2003) Neuroblastoma: biological insights into a clinical enigma. Nat. Rev. Cancer 3: 203-216

26. El Badry OM, Romanus JA, Helman LJ, Cooper MJ, Rechler MM and Israel MA (1989) Autonomous growth of a human neuroblastoma cell line is mediated by insulin-like growth factor II. J. Clin. Invest. 84: 829-839

27. Tanno B, Negroni A, Vitali R, Pirozzoli MC, Cesi V, Mancini C, Calabretta B and Raschella G (2002) Expression of insulin-like growth factor-binding protein 5 in neuroblastoma cells is regulated at the transcriptional level by c-Myb and BMyb via direct and indirect mechanisms. J. Biol. Chem. 277: 23172-23180

28. Cesi V, Vitali R, Tanno B, Giuffrida ML, Sesti F, Mancini C and Raschella G. (2004) Insulin-like growth factor binding protein 5 (IGFBP-5): contribution to growth and differentiation of neuroblastoma cells. Ann. NY. Acad. Sci. 1028: 1-10

29. Zeng Y, Wagner EJ and Cullen BR (2002) Both natural and designed micro RNAs can inhibit the expression of cognate mRNAs when expressed in human cells. Mol. Cell 9: 1327-1333

30. McManus MT and Sharp PA (2002) Gene silencing in mammals by small interfering RNAs. Nat. Rev. Genet. 3: 737-747

31. Sui G, Soohoo C, Affar EB, Gay F, Shi Y, Forrester WC and Shi Y (2002) A DNA vector-based RNAi technology to suppress gene expression in mammalian cells. Proc. Natl. Acad. Sci. USA 99: 5515-5520

32. Kunkel GR, Maser RL, Calvet JP and Pederson T (1986) U6 small nuclear RNA is transcribed by RNA polymerase III. Proc. Natl. Acad. Sci. USA 83: 8575-8579

33. Paddison PJ, Caudy AA, Bernstein E, Hannon GJ and Conklin DS (2002) Short hairpin RNAs (shRNAs) induce sequence-specific silencing in mammalian cells. Genes Dev. 16: 948-958

34. Sledz CA, Holko M, de Veer MJ, Silverman RH and Williams BR (2003) Activation of the interferon system by short-interfering RNAs. Nat. Cell Biol. 5: 834-839

35. Bridge AJ, Pebernard S, Ducraux A, Nicoulaz AL and Iggo R (2003) Induction of an interferon response by RNAi vectors in mammalian cells. Nat. Genet. 34 263-264

36. Lovat PE, Di Sano F, Corazzari M, Fazi B, Donnorso RP, Pearson AD, Hall AG, Redfern CP and Piacentini M (2004) Gangliosides link the acidic sphingomyelinase-mediated induction of ceramide to 12-lipoxygenasedependent apoptosis of neuroblastoma in response to fenretinide. J. Natl. Cancer Inst. 96: 1288-1299

37. Kouhara H, Koga M, Kasayama S, Tanaka A, Kishimoto T and Sato B (1994) Transforming activity of a newly cloned androgen-induced growth factor. Oncogene 9: 455-462

38. Ewton DZ, Coolican SA, Mohan S, Chernausek SD and Florini JR (1998) Modulation of insulin-like growth factor actions in L6A1 myoblasts by insulin-like growth factor binding protein (IGFBP)-4 and IGFBP-5: a dual role for IGFBP-5. J. Cell Physiol. 177: 47-57

39. Byun Y, Chen F, Chang R, Trivedi M, Green KJ and Cryns VL (2001) Caspase cleavage of vimentin disrupts intermediate filaments and promotes apoptosis. Cell Death Differ. 8: 443-450 
40. Gaetano C, Matsumoto K and Thiele CJ (1991) Retinoic acid resistant neuroblastoma cells and the expression of insulin-like growth factor-ll. Prog. Clin. Biol. Res. 366: 165-172

41. Parker A, Rees C, Clarke J, Busby Jr H and Clemmons DR (1998) Binding of insulin-like growth factor (IGF)-binding protein-5 to smooth-muscle cell extracellular matrix is a major determinant of the cellular response to IGF-I. Mol. Biol. Cell 9: 2383-2392

42. Schwab M and Bishop JM (1988) Sustained expression of the human protooncogene MYCN rescues rat embryo cells from senescence. Proc. Natl. Acad. Sci. USA 85: 9585-9589

43. Shimizu S, Narita M and Tsujimoto Y (1999) Bcl-2 family proteins regulate the release of apoptogenic cytochrome $\mathrm{c}$ by the mitochondrial channel VDAC. Nature 399: 483-487

44. Lovat $P E$, Ranalli $M$, Bernassola F, Tilby $M$, Malcolm AJ, Pearson $A D$, Piacentini M, Melino G and Redfern CP (2000) Synergistic induction of apoptosis of neuroblastoma by fenretinide or CD437 in combination with chemotherapeutic drugs. Int. J. Cancer 88: 977-985

45. Gabbitas B and Canalis E (1997) Retinoic acid regulates the expression of insulin-like growth factors I and II in osteoblasts. J. Cell Physiol. 172: 253-264

46. Pahlman S, Meyerson G, Lindgren E, Schalling M and Johansson I (1991) Insulin-like growth factor I shifts from promoting cell division to potentiating maturation during neuronal differentiation. Proc. Natl. Acad. Sci. USA 88: 9994-9998

47. Raschella G, Negroni A, Sala A, Pucci S, Romeo A and Calabretta B (1995) Requirement of $b$-myb function for survival and differentiative potential of human neuroblastoma cells. J. Biol. Chem. 270: 8540-8545

48. Raschella G, Tanno B, Bonetto F, Negroni A, Claudio PP, Baldi A, Amendola R, Calabretta B, Giordano A and Paggi MG (1998) The RB-related gene Rb2/p130 in neuroblastoma differentiation and in B-myb promoter down-regulation. Cell Death Differ. 5: 401-407 